\title{
Environmental governance under Bolsonaro: dismantling institutions, curtailing participation, delegitimising opposition
}

\author{
Roberto Goulart Menezes $(\mathbb{D}) \cdot$ Ricardo Barbosa Jr. (ID
}

Received: 9 July 2020 / Revised: 11 July 2021 / Accepted: 16 July 2021 / Published online: 12 August 2021

(C) Springer Fachmedien Wiesbaden GmbH, ein Teil von Springer Nature 2021

\begin{abstract}
Tensions concerning environmental governance have increased in Brazil since the far-right came to power in 2016. We offer insight into this process by analysing the first two years of Jair Bolsonaro's (2019-ongoing) environmental policies-namely, how Brazil's environmental protection arrangements are being dismantled. We find that the Bolsonaro administration centralises environmental governance in Brazil through complementary authoritarian and populist means. First in restricting participatory decision-making spaces such as the National Environmental Council (Conama) and the National Council of the Legal Amazon (CNAL), and, second, by attacking indigenous and traditional peoples, NGOs, scientists, and other environmental defenders. To illustrate the authoritarian dimension of Bolsonaro's environmental governance, we carry out a political-institutional analysis of contemporary Brazilian environmental politics and then exemplify the ways and extent to which attacks against environmental defenders is a constituent part of Bolsonaro's environmental populism. We hold that such attacks are not merely rhetorical but a political tactic to legitimise Bolsonaro's authoritarian environmental governance in the promotion of 'total extractivism' while maintaining a populist appeal.
\end{abstract}

Keywords Authoritarian populism $\cdot$ Bolsonaro $\cdot$ Brazil $\cdot$ Environmental governance $\cdot$ Environmental populism $\cdot$ Political participation

\footnotetext{
Roberto Goulart Menezes

University of Brasilia, Brasilia, Brazil

E-Mail: rgmenezes@unb.br

Ricardo Barbosa Jr. ( $\square)$

Department of Geography, University of Calgary, 2500 University Drive

NW, T2N 1N4 Calgary, Alberta, Canada

E-Mail: ricardo.barbosajr@ucalgary.ca
} 


\section{Umwelt-Governance unter Bolsonaro: Abbau von Institutionen, Einschränkung von Partizipationsmöglichkeiten und Delegitimierung der Opposition}

Zusammenfassung Die Spannungen in Bezug auf die Umweltpolitik haben in Brasilien zugenommen, seit die extreme Rechte 2016 an die Macht kam. Wir bieten einen Einblick in diesen Prozess, indem wir die ersten zwei Jahre von Bolsonaros Umweltpolitik (seit 2019) analysieren und aufzeigen, wie in Brasilien Umweltschutzvorkehrungen demontiert werden. Wir zeigen, dass die Regierung unter Bolsonaro die Umweltpolitik in Brasilien unter Rückgriff auf autoritäre und populistische Mittel zentralisiert. Dies geschieht erstens, durch die Einschränkung partizipativer Entscheidungsräume wie dem Nationalen Umweltrat (Conama) und dem National Council of the Legal Amazon (CNAL), und zweitens, durch Angriffe auf indigene und traditionelle Völker, NGOs, Wissenschaftler und andere Umweltschutzgruppen. Um die autoritäre Dimension von Bolsonaros Umweltpolitik zu veranschaulichen, führen wir eine politisch-institutionelle Analyse der jüngsten brasilianischen Umweltpolitik durch und zeigen dann exemplarisch auf, wie und in welchem Ausmaß Angriffe gegen Umweltschützer ein wesentlicher Bestandteil von Bolsonaros Umweltpopulismus sind. Wir stellen fest, dass solche Angriffe nicht nur rhetorisch zu verstehen sind, sondern eine politische Taktik zur Legitimierung von Bolsonaros autoritärer Umweltpolitik darstellen, um den ,totalen Extraktivismus“ zu fördern.

Schlüsselwörter Autoritärer Populismus · Bolsonaro · Brasilien · UmweltGovernance $\cdot$ Umwelt-Populismus · Politische Partizipation

\section{Introduction}

As right-wing authoritarian populists reach positions of power across the globe, a new research agenda emerges (Rydgren 2018; Scoones et al. 2018). We contribute to ongoing research into the environmental policies of these far-right populist leaders (e.g., Lockwood 2018; McCarthy 2019) by presenting and analysing the Brazil case. Brazil's 'right turn' has become a source of concern among environmental activists and scientists due to the erosion of environmental protection policies (Escobar 2018; Abessa et al. 2019; Barbosa et al. 2021).

The effects of President Jair Bolsonaro's (2019-present) regressive environmental policies are perhaps most apparent in the Amazon. In August 2019, malicious forest fires accelerated destruction of the forest and led to international repercussion (see Gudynas 2020) which, with indirect incentive from Bolsonaro himself, ${ }^{1}$ compelled the administration to offer explanations. However, at no time did the Bolsonaro administration repudiate the destruction of the Amazon rainforest. The fires were so vast that the city of São Paulo, the most populous in Brazil, located approximately 2500 kilometres away, became dark during the day from the smoke. Deforestation data in Brazil show a 34\% increase over a period of 12 months with over 10,000

\footnotetext{
1 See http://piaui.folha.uol.com.br/materia/the-environment-as-an-obstacle/. Accessed: 01.06.20.
} 
square kilometres lost (INPE 2020), the highest deforestation numbers in a decade (see also Kröger 2020a). In destroying the forest, extractivist interests advance across indigenous and traditional peoples' 2 territory, threatening their ways of life and very survival (Gudynas 2015).

Bolsonaro's environmental policies, outlined during his 2018 presidential bid (see Bolsonaro 2018), contrast prior stances. The environmental policies of Luiz Inácio Lula da Silva (2003-2010) and Dilma Rousseff (2011-2016), from the centreleft Workers' Party (PT), conflated environmental concerns with neodevelopmentalist goals (see Kröger 2020b), prioritising the 'ecological modernisation' paradigm (Zhouri 2014) which sought to maintain the status quo and promote 'green capitalism' (Hopwood et al. 2005; Svampa 2019). After the 2016 coup d'etat, ${ }^{3}$ Michel Temer (2016-2018), from the centre-right Brazilian Democratic Movement (MDB), implemented austerity measures such as spending caps and budget cuts while adopting an approach that targeted specific regions for development, including protected indigenous and environmental reserves (Faria et al. 2018). Bolsonaro's authoritarian populist environmental policies have furthered Temer's authoritarian measures through institutional and legal changes that restrict spaces for participatory decisionmaking, but surpass Temer's approach by openly targeting environmental defenders themselves (see Guajajara 2020).

Academic literature discloses how social policies legitimised PT's contradictory environmental agenda, which favoured commodities destined for the international market (Andrade 2016; Sauer 2017), a process called 'neoextractivism' (Acosta 2013; Arsel et al. 2016). ${ }^{4}$ Yet, we are still uncovering the strategies Brazil's farright populist leader employs to legitimise intensified extractivism (see Soyer and Barbosa Jr 2020). Bolsonaro's environmental policies, the focus of this paper, are largely understood to favour a development agenda anchored in market interests irrespective of the environmental costs. The current administration's environmental governance is directed exclusively towards allies in the extractivist sector (e.g., large-scale monoculture, ranching, mining, loggers, land grabbers, and others). We suggest that Bolsonaro-era natural resource extraction is perhaps best understood through the notion of 'total extractivism' (Dunlap and Jakobsen 2020), defined as a global imperative of the capitalist economy that occurs through the use of violent technologies.

During his first year in office, Bolsonaro implemented measures that radically changed Brazil's environmental governance. These include extinguishing the Min-

\footnotetext{
2 Approximately 650,000 families recognise themselves as traditional peoples in Brazil. For a map of the various traditional peoples and communities in Brazil see http:/g1.globo.com/natureza/desafio-natureza/ noticia/2019/10/29/650-mil-familias-se-declaram-povos-tradicionais-no-brasil-conheca-os-kalungasdo-maior-quilombo-do-pais.ghtml. Accessed: 01.06.20.

3 Rousseff's 2016 impeachment is best understood as a 'parliamentary coup.' Singer (2018, pp. 16-17 our translation) explains that "impeachment constitutes a new type of instability in Latin America, which has replaced the old military coups," and elaborates that "in the Brazilian case, instability created by the parliamentary coup put democracy under threat, but it did not dissolve it.".

${ }^{4}$ The terms 'neodevelopmentism' and 'neoextractivism' outline a very similar process in different ways, the focus respectively being on development itself and the extractivist-social policy nexus that characterises it.
} 
istry of Foreign Affairs' climate change division, ${ }^{5}$ threatening to pull-out of the Paris Agreement, giving up hosting the 2019 COP25 Climate Conference, and degrading deforestation monitoring. The federal government's abrupt withdrawal from global environmental governance tarnishes the country's international image (Levis et al. 2020) and brings uncertainty to Brazil's capacity to fulfil assumed international commitments. Yet, paradoxically, ruralists, and even the Agricultural Minister herself, have recognised that the negative international repercussions of Bolsonaro's environmental measures and his refusal to participate in global environmental governance is bad for international trade. ${ }^{6}$ Importantly, possible international retaliation to environmental degradation (e.g., boycott of meat or soy exports) remains the extractivist sector's only fear.

Concurrent to and associated with Brazil's lack of engagement in global environmental governance, we observe, in Brazil, a centralisation of environmental governance. ${ }^{7}$ Such a phenomenon raises the question: through what means has the Bolsonaro administration been able to centralise Brazil's environmental governance?

To answer this question, we detail the institutional and legal changes that have allowed the Bolsonaro administration to centralise Brazil's environmental governance through authoritarian measures that restrict participation, then, we seek to explain how such measures are legitimised through environmental populism. This paper is informed by an archival analysis of legislation, documents, and recent media stories on environmental politics in Brazil focusing on the Bolsonaro administration's public environmental agenda. Here, we present our deconstructions of the material collected, supported and complemented by a discourse analysis of public statements and supplementary research data.

Our paper's contributions are three-fold. First, we explore the environmental approach taken by the Bolsonaro administration in Brazil and, through a politicalinstitutional analysis, we identify the concrete steps the administration has taken to expand extractivism in the country. Second, by drawing attention to the impact of far-right governance on environmental protection in the Global South, we bring together the literature on authoritarian populism and environmental protection. Third, we operationalise the concept of 'environmental populism' through the conceptual framework of authoritarian populism to draw out key issues and demonstrate the global relevance of the approach.

\section{Authoritarian populism and environmental politics}

The contemporary global rise of the far-right has drawn great attention across society and academia, setting political research on a new path (Walker et al. 2018; Li 2019). One such line of inquiry hopes to create conditions to conceptualise the far-

\footnotetext{
5 This is not a mere organisational change; it reflects how the Minister of Foreign Affairs himself does not believe in climate change (Casarões und Flemes 2019).

6 See http://economia.uol.com.br/noticias/estadao-conteudo/2020/07/05/o-agronegocio-nao-precisa-daamazonia-diz-ministra-da-agricultura.htm. Accessed: 01.06.20.

7 See Ostrom (2010) for the effects of centralised environmental governance.
} 
right across geographies through the 'authoritarian populism' framework (Scoones et al. 2018) by recognising common elements, such as government restriction of political participation and politics conducted in a manner that is socially selective and harmful to marginalised groups. This framework emphasises how far-right leaders simultaneously create 'difference' and 'belonging' (Kiely 2020). In such a way, the far-right ascends to power though populist rhetoric situated in response to grievances that result from the failings of neoliberalism (Eichengreen 2018; Broz et al. 2021). Far-right leaders mobilise through these grievances, offering authoritarian measures in response (Bruff and Tansel 2019).

In mapping the emerging literature, we have found comprehensive explorations into far-right politics and identified a gap: a lack of studies on far-right environmentalism with a focus on the so-called Global South. For example, Rydgren's (2018) handbook covers a range of subjects, but importantly does not have a chapter that focuses specifically on how such regimes impact the environment, nor one that explores far-right populism outside the Global North. When far-right environmentalism is studied, cases tend to likewise be restricted to the so-called Global North (see Forchtner 2020). The few empirical cases are mostly focused on the United States (US) and Europe, disregarding far-right environmentalism in countries such as India (Vanaik 2017), the Philippines (Heydarian 2018), Bolivia (Tilzey 2019), Brazil (Andrade 2019), and others.

Research on far-right environmentalism is moving towards further explorations of climate and environmental populism (Lockwood 2018), especially in association with contemporary environmental governance (McCarthy 2019). This is key as far-right regimes have found legitimacy in environmental deregulation and climate change denial (Forchtner 2019; Żuk and Szulecki 2020). Interestingly, the farright simultaneously promotes ecological devastation and denies its negative consequences in an effort to reinforce their own political power (Neimark et al. 2019). Yet, the far-right has been moving beyond mere 'climate denial' and opposition to climate action by effectively governing (through) the environment by incorporating 'green politics' into their agenda (Aronoff 2019). ${ }^{8}$ These recent developments converge to position far-right ideology as a major question and focus for environmental activists and researchers (Stoner 2020).

\section{Situating Brazil's environmental governance}

\subsection{An overview of development in Brazil}

To understand Bolsonaro-era environmental policy in Brazil, we must first present the recent history of development in Brazil and how this has shaped different environmental perceptions. Economic strategies and policies guided by assumptions of national development, first implemented in the 1930s (Sá et al. 2008), were adopted by the civil-military dictatorship (1964-1985) setting economic exploitation of the

\footnotetext{
${ }^{8}$ See also http://theconversation.com/beware-far-right-arguments-disguised-as-environmentalism- 134830. Accessed: 01.06.20.
} 
Legal Amazon on a new path (Carneiro 2002). ${ }^{9}$ During this period, the dictatorial regime provided subsidised credit for national and foreign investors to implement so-called 'development' projects in the region. The dictatorship's developmental ambitions led to the building of megaprojects (e.g., the Tucuruí Hydroelectric Plant), to the distribution of land to large companies, and to the opening of several roads (e.g., the Transamazônica). In pursuit of the so-called 'economic miracle,' the Amazon and its peoples were exploited irrespective of the cost. Nevertheless, the high rates of economic growth registered in Brazil at the time did not result in any substantive change to the country's unequal social structure (Gonçalves 2013).

In the 1990s, Washington Consensus economic and political guidelines were widely adopted across Latin America. Proponents of the neoliberal programme argued that to overcome the recession it was necessary to carry out deep structural economic reforms to resume development. The World Bank reformulated its economic, political, and intellectual programme in the early 2000s and began to highlight the importance of the relationship between society and nature, while maintaining the economic centrality of privatisation and liberalisation (Pereira 2015).

The 14 years in which PT (2003-2016) was in power seemed to usher in a 'postneoliberal' period in Brazil's economy and politics (Sader 2009). When former President Luiz Inácio Lula da Silva (2003-2010) was still an opposition leader, ${ }^{10}$ he spoke out against the way Brazil was subjected to impositions of globalisation and multilateral organisations that imposed structural adjustment policies (Samuels 2004). Despite this, during his administration, Lula da Silva maintained an orthodox economic policy and carried out second generation structural reforms in accordance with a reformulated version of the World Bank's political programme (Gonçalves 2013; Pereira 2015). During Lula da Silva's second term, 'untangling' capitalism through development with social inclusion was positioned as a strategic objective, marking a pronounced return to a developmental project that dates from the 1930 to the 1990s (Fiori 2007), when it was interrupted by neoliberalism. The return to precepts of the 'old' development project was rebranded as neodevelopmentism (North and Grinspun 2016). The 'old' national development efforts and PT's 'new' programme differ in that the latter presumed that development would promote both social inclusion and environmental sustainability.

Environmental policy tensions marked PT's administration. Once in office, PT's historic promotion of environmental justice ${ }^{11}$ was displaced as the government aligned with its broader political coalition (Hunter 2010). At the heart of 'ecological modernisation' lies a belief in managerial and technical solutions that permeate a hegemonic vision of so-called 'sustainable development' (Teixeira et al. 2021).

\footnotetext{
9 The Legal Amazon covers $49 \%$ of the Brazilian territory, possesses roughly half of the country's fresh water, and contains an extensive socio-biodiversity heritage.

10 While Lula's right-wing opposition insisted in derogatively branding him as a 'populist' because of PT's social policies. In Latin America the term populist can have very different meanings (Scoones et al. 2018), we reason that Lula is best described as a 'popular' leader instead (see also Singer 2012).

${ }^{11}$ Chico Mendes, one of the most import figures who fought for environmental justice in Brazil and was affiliated with PT, created a collective action strategy known as 'forest peoples' that brought together rural workers, rubber tappers, indigenous peoples and other traditional communities (Ventura 2003). Mendes was murdered in 1988 at the behest of latifundiário (large landholders).
} 
Such a paradigm determined PT's stance on questions of the environment, land, and megaprojects. Importantly, PT insisted that wide-ranging extractive projects, which are clearly not sustainable, were a step toward sustainability. The inherent contradictions of this rationality justified concessions for extractivist interests and led to tensions with PT's social base.

Repeated concessions to extractivist demands led the PT administration to once again favour megaprojects in the Amazon (Teixeira et al. 2021) and to promote agribusiness interests (Sauer et al. 2018), leading to conflicts with sectors that historically supported PT and casting doubts on its efforts to 'untangle capitalism' in Brazil. As de Castro (2014) explains, environmental tensions grew as PT-era economic growth relied on commodities, with significant and growing energy demands leading to the advancement of megaprojects financed with public resources (e.g., the Belo Monte Hydroelectric Dam, see Fearnside 2006). The Growth Acceleration Programme (PAC) led to the construction of controversial projects with special financing credits from the Brazilian Development Bank (BNDES). As Diniz (2013, p. 11 our translation) explains, this ended up reinforcing "a productivist paradigm from the past that should gradually lose strength with changes in the energy matrix." Bishop Luiz Flávio Cappio's 24-day hunger strike in protest of the São Francisco River's transposition had great repercussion across the country and, in particular, the party's social base. ${ }^{12}$

When Lula da Silva took office, progressive food policies were implemented (Wittman and Blesh 2017; Coca 2021), but agribusiness interests expanded simultaneously (Andrade 2016; Sauer 2017). Marina Silva, an important environmental leader who was Lula's Environment Minister (Nunes and Peña 2015), left the government precisely because of the concessions made to predatory agribusiness. Such measures were continued and intensified during the Dilma administration with the Forest Code Reform (Law $n^{\circ} 12,651 / 2012$ ) and significant reduction in the rate of indigenous land demarcation. In such a way, PT's developmentalist agenda focused on social inclusion and expansion of the internal market for mass consumption (Singer 2012). Ecological modernisation became a counterpoint to the struggle for environmental justice, which PT insisted on as a conciliatory proposal of supposed 'green capitalism.' In fact, the paradigm depoliticised the environmental agenda by creating recurrent concessions to extractivist interests.

PT's environmental and agricultural policies may seem contradictory (Niederle et al. 2019). However, the coexistence of such conflicting stances makes sense as it perpetuated the power of the state itself and the capacity of those who govern through it (Rocha and Barbosa Jr 2018). While progressive governments in Latin America have represented an alternative to exclusively market-oriented reforms, post-neoliberal contradictions have not been sustained in the long run (VergaraCamus and Kay 2017; Coca 2021). The so-called 'new' far-right has been successful in exploiting discontent with (post-)neoliberal social policies (Fischer 2020), which led scholars to argue that these contradictions set the stage for the right's rise to power in Brazil (Pahnke 2018; Braga and Purdy 2019; de Souza 2020). In such

12 For more on religious leaders' engagement with environmental and land rights in Brazil, see Barbosa Jr and Roriz (2021). 
a way, Andrade (2019) claims that the rise of the far-right in Brazil is directly linked to PT's choice to position themselves as a representative of interests 'from below' while advancing a political project that promoted interests 'from above.'

\subsection{The institutional construction of environmental protection in Brazil}

To assess the means through which the Bolsonaro administration has centralised environmental governance, we need to understand how environmental protection was institutionalised. In Brazil, environmental protection gained momentum in the 1970s, after the 1st United Nations Conference on the Environment in Stockholm (1972). In response to Brazil's calamitous participation in Stockholm, the dictatorship instituted the Special Secretariat for the Environment (SEMA) with a ninemember Environment Advisory Council through Decree $\mathrm{n}^{\circ} 73,030 / 73$. This was the first federal agency to specifically address environmental issues. Professor Paulo Nogueira Neto, SEMA's first secretary, held the position between 1974-1986 and made important contributions towards structuring environmental protection policy in Brazil. Nogueira Neto played a decisive role in the creation of the National Environment Policy, approved by Congress in 1981, and the National Environment Council (Conama), with the participation of civil society, regulated via Decree $\mathrm{n}^{\circ}$ $88,351 / 83$. Since then, Conama has played a central role in formulating proposals for environmental protection in Brazil.

When a new Constitution was drawn up to democratise Brazil (1986-1988), Conama actively engaged with proposals that contributed to the elaboration of the Federal Constitution's (1988) Articles 170 and 225 (Chapter IV - Environment). Environmental protection as a constitutional guarantee is considered one of organised civil society's main achievements against powerful economic interests and the threats posed by those that seek to exploit the country's natural resources. With the creation of the Brazilian Institute for the Environment and Renewable Natural Resources (IBAMA) in 1989 and a specific Ministry for the Environment in 1992, Brazil formed an institutional framework capable of meeting the challenges of environmental protection (de Moura 2016). Still, despite having specific institutional mechanisms for environmental protection, many conflicts remain and, in some cases, have even worsened.

\section{Dismantling institutions: the environmental policy of Brazil's far- right (2016-ongoing)}

The 2016 coup d'état led to a reaffirmation of neoliberal precepts based on the logic of austerity, which marked the end of neodevelopmentism in Brazil. During Michel Temer's administration (2016-2018), austerity was inscribed into the Federal Constitution through Congress' approval of Constitutional Amendment $\mathrm{n}^{\circ} 95$ in December 2016. The new fiscal regime instituted a 20-year ceiling on public expenditures instead of increased taxation (Tavares and Silva 2020) leading to the accelerated privatisation and denationalisation of the economy which, in turn, has accentuated stagnation, reinforced indebtedness, and reduced the national govern- 
ment's capacity to respond to emerging and continued crises (Schincariol and Yeros 2019) such as COVID-19 (Pinheiro et al. 2020). Allegations of corruption and the possibility of impeachment led to Temer's alignment with the ruralist caucus. To secure his presidency, Temer weakened deforestation monitoring and proposed a review of environmental conservation areas to allow for extractivism in exchange for support of 230 congressional votes. Temer also signed, during his last days in office, Provisional Measure $\mathrm{n}^{\circ} 867 / 18$, amending the Forest Code to grant amnesty to deforesters.

Since Bolsonaro came to power in January 2019, his administration has endeavoured first to neutralise and, then, dismantle institutional and legal environmental protection arrangements. Bolsonaro's (2018) environmental policies were originally outlined in campaign promises, through which the then candidate incorporated the interests of the extractivist sector and, in turn, projected environmental policies that led extractivist sectors to embrace his candidacy. Bolsonaro went so far as to promise to terminate the Ministry of the Environment (MMA). ${ }^{13}$ In this way, environmental policies favourable to Brazilian extractivist interests help explain the political support Bolsonaro receives from this sector.

Bolsonaro's environmental policy is exemplified through the institutional and personnel changes made. Despite Bolsonaro's campaign promise and strong pressure from ruralists - like the Land Affairs Secretary Nabhan Garcia, who was at one point considered for the role Minister of Agriculture (MAPA)_MMA was not closed. Instead, MMA has been hollowed out through a distribution of its powers through a restructuring of competencies and personnel. For instance, the Secretariat for Climate Change and Forestry was eliminated, with forestry now being attributed to MAPA. Bolsonaro appointed Ricardo Salles to head MMA. A staunch defender of predatory agribusiness, Salles shares Bolsonaro's belief that the economy must not be curtailed by environmental concerns. As Environment Minister, Salles' first measure was to target civil servants committed to executing environmental protection legislation (e.g., singling out, harassment, and even relocation). ${ }^{14}$ In place of well-prepared civil servants, the Environment Minister appointed military personnel aligned with Bolsonarism (see also Pfrimer and Barbosa Jr 2020). ${ }^{15}$ All five of Chico Mendes Institute for Biodiversity Conservation (ICMBio) Regional Manager roles were occupied by appointed officials with military backgrounds. Reducing the number of ICMBio Regional Manager roles, from eleven to five, and then militarising the entire command structure - steps that erase the institutional memory of environmental protection agencies and attest to how environmental governance is being centralised.

\footnotetext{
13 See www.oeco.org.br/noticias/bolsonaro-confirma-promessa-ministerio-do-meio-ambiente-deixarade-existir. Accessed: 01.06.20.

14 See http://deolhonosruralistas.com.br/2018/12/20/justica-diz-que-ricardo-salles-perseguiu-servidorespara-cometer-e-encobrir-irregularidades. Accessed: 01.06.20.

15 See www.nexojornal.com.br/expresso/2019/04/28/As-crises-e-a-militariza\%C3\%A7\%C3\%A3o-doMinist\%C3\%A9rio-do-Meio-Ambiente and theintercept.com/2020/02/18/bolsonaro-mourao-moro-esvaziam-ibama/. Accessed: 01.06.20.
} 
To profoundly change Brazil's environmental policy, the Bolsonaro administration would have to enact changes in environmental legislation, which they have so far been unable to do. As a result, the administration has focused primarily on infraConstitutional legislation which does not require Congressional approval (Araújo 2020; Barbosa et al. 2021). A video of Bolsonaro's 22 April 2020 cabinet meeting, released a month later as part of an investigation of the President's oversight of and meddling in the Federal Police, offers us a unique view into the innerworkings of the Bolsonaro administration. In the recorded cabinet meeting, the Environment Minister states that: "in terms of press coverage, we are at a good moment, because COVID-19 is the only thing they talk about, and we need to push through changes [ir passando a boiada, literary 'push the cattle through'], to change all the regulation and simplify norms" (Policia Federal 2020, p. 20 our translation). Salles goes on to claim "we don't need Congress because things that need Congress, with this current mess, are not going to pass" (Policia Federal 2020, p. 20 our translation). The Environment Minister's strategy to enact environmental deregulation in circumventing both the legislative and public opinion while attention is diverted by COVID-19 is another example of the extent to which the Bolsonaro administration has been centralising environmental governance in Brazil. An open letter signed by all eight former Environment Ministers has condemned Salles and, in early July 2020, Federal Prosecutors have demanded he be removed as Environment Minister through an action that alleges wilful disruption of environmental protection mechanisms. ${ }^{16}$ Most recently, after the biggest recorded seizure of illegal lumber from the Amazon, Salles became the focus of a Federal Police's Supreme Court-sanctioned investigation that ultimately led to him being fired. ${ }^{17}$

By extinguishing specialised secretariats, appointing an anti-environmentalist as Minister, substituting civil servants, and reducing regulations, the application of even the strictest environmental legislation is weakened (Abessa et al. 2019; Barbosa et al. 2021). Deregulation, through such means, has sought to erode environmental protection in any possible way. Environmental legislation and institutions remain without effective conditions for compliance. These developments allow us to understand why deforestation does not concern the Bolsonaro administration. Deforestation indicates that the way in which the Bolsonaro administration governs the environment is working. ${ }^{18}$

\footnotetext{
${ }^{16}$ See www.reuters.com/article/us-brazil-environment/ex-ministers-blast-bolsonaro-for-dismantlingbrazils-environment-protections-idUSKCN1SE2IQ and www.valor.com.br/international/news/6443349/ prosecutors-request-court-remove-environment-minister. Accessed: 01.06.21.

${ }_{17}$ See http://www1.folha.uol.com.br/internacional/en/brazil/2021/04/federal-police-ask-to-supremecourt-investigate-minister-of-the-environment-for-disrupting-environmental-inspection.shtml and http:// noticias.uol.com.br/meio-ambiente/ultimas-noticias/redacao/2021/06/02/carmen-lucia-autoriza-aberturade-inquerito-contra-ministro-ricardo-salles.htm. Accessed: 01.06.21.

${ }^{18}$ Deforestation is not the only way to promote economic development. For alternatives, see Stabile et al. (2020) and Siqueira-Gay et al. (2020).
} 


\section{The Bolsonaro administration centralises environmental governance in Brazil}

\subsection{Curtailing participation: restricting participatory decision-making spaces}

To offer evidence of how the Bolsonaro administration has been restricting participatory decision-making spaces, we focus on the National Environmental Council (Conama) and the National Council of the Legal Amazon (CNAL).${ }^{19}$ From it's institution in 1982, until April 2019, Conama had 96 member seats. Decree no 9806/19 reduced this total to a mere 23 members. The drastic reduction in the number of seats impedes effective civil society representation that previously accounted for 22 members and now is left with only four seats. ${ }^{20}$ In restricting the number of members in Conama, the Bolsonaro administration practically excludes civil society participation from environmental policy-making. Conama, which establishes Brazil's National Environmental Policy, is now under the control of the extractivist sector that benefit from Bolsonaro's policies and openly defend that much of the Brazilian environmental legislation, which was constructed over four decades, be repealed. The very legislation that led Brazil to prominence among international environmental forums (Araújo 2020). As such, efforts to restrict civil society access to participatory decision-making spaces is key in the Bolsonaro administration's pursuit to radically undermine environmental protection.

In response to increased attention to environmental destruction in the Amazon, the Bolsonaro administration transferred CNAL, which had been presided over by MMA since 1995, to the Vice-President's Office through Decree $n^{\circ} 10,239 / 20$. CNAL is now chaired by Vice-President General Hamilton Mourão and composed of 14 ministers. Importantly, CNAL currently has no participation from civil society nor that of governors from the Amazon region, who previously all had seats in CNAL (see Decree $\mathrm{n}^{\circ}$ 1541/95). CNAL has become a strategic component in the Bolsonaro administration's active efforts to concentrate regulatory powers that belonged to MMA, Conama, and others. Now, all questions related to the Legal Amazon go through General Mourão himself.

Bolsonaro's environmental authoritarianism keeps organised civil society from participating in decision-making spaces like Conama. Environmental governance arrangements that were previously occupied by a variety of actors with competing interests are now being centralised in the federal government and deprived of any possibility for real opposition. So far, CNAL has taken no effective action to reverse environmental degradation or intensified extractivism in the Amazon. We reason that CNAL serves the Bolsonaro administration a different purpose: to persuade

\footnotetext{
19 While we focus here on Conama, many other participatory spaces have been closed down by the farright in a process that became known as 'revogaço' (mass repeal)—e.g., the day he took office, Bolsonaro closed the civil society-led National Council for Food and Nutrition Security (CONSEA), see Soyer and Barbosa Jr (2020).

${ }^{20}$ See www.oeco.org.br/reportagens/governo-cumpre-plano-e-esvazia-conama. Accessed: 01.06.20.
} 
foreign investors and Brazil's main trade partners that the current administration is committed to environmental conservation. ${ }^{21}$

\subsection{Delegitimising opposition: attacking environmental defenders}

The Bolsonaro administration has also actively sought to diminish the legitimacy, agency, and voices of those who had previously engaged with Brazil's environmental agenda. The administration and the president himself have targeted diverse environmental defenders that range from protected minority groups to scientists-exemplified by the firing of the head scientist of the government agency that revealed a steep increase in deforestation in the Amazon. ${ }^{22}$ Bolsonaro also accuses NGOs of 'internationalising' the Amazon and has gone further by claiming NGOs themselves set fire to the forest. ${ }^{23}$ In addition to these examples, attacks on indigenous and traditional peoples' very personhood can be understood as an effort to challenge the legitimacy of their environmental claims. Bolsonaro has questioned the humanity of indigenous peoples and quilombolas (traditional Afro-Brazilian communities, see Leite 2015) with racist statements like "the 'indians' are evolving, more and more they are human beings like us" and "quilombolas are not even good enough to breed" made in Rio's Hebrew Club. ${ }^{24}$ We reason that these attacks are politically motivated and not only rhetorical. In Brazil, indigenous and traditional peoples cannot be dissociated from nature and environmental protection (Milanez 2020). Brazilian environmental protection is intrinsically linked to indigenous and traditional peoples. In this way, it is not a question of climate or environmental protection, but rather socio-environmental protection.

Environment policies in Brazil are in fact socio-environmental since ensuring the existence and rights of specific peoples has been one of the most effective forms of environmental protection (Reis da Silva 2015). ${ }^{25}$ In addition to not demarcating any new areas, the Bolsonaro administration has made repeated attempts to review already demarcated indigenous lands. So far, these attempts have been unsuccessful. As a result, recent efforts by the administration have focused on creating conditions for extractivism in indigenous territories in the Amazon where 180 indigenous

\footnotetext{
21 On one particularly illustrative episode, Vice-President Mourão took ambassadors on a tour of the Amazon without visiting areas affected by fires and deforestation, see http://brasil.elpais.com/brasil/ 2020-11-10/turne-de-embaixadores-pela-amazonia-termina-sem-visitar-areas-afetadas-por-queimadase-desmatamento.html. Accessed: 01.06.21.

22 See www.nytimes.com/2019/08/02/world/americas/bolsonaro-amazon-deforestation-galvao.html. Accessed 01.06.20.

23 See www.theguardian.com/world/2019/aug/21/jair-bolsonaro-accuses-ngos-setting-fire-amazonrainforest. Accessed: 01.06.20.

24 See www.survivalinternational.org/articles/3540-Bolsonaro (23.01.20) and www.youtube.com/watch? $\mathrm{v}=\mathrm{ks} 0 \mathrm{dgE} 8 \mathrm{jpkw}$ (05.04.17), our translation. Accessed: 01.06.20.

25 It is important to recognise that beyond the legal protected status of their territories, indigenous and traditional peoples play an active and central role in environmental governance (e.g., in promoting norm diffusion, Chase 2019).
} 
peoples (about $80 \%$ of all indigenous peoples in Brazil) are located. ${ }^{26}$ These examples illustrate how Bolsonaro's environmental policies include efforts that reach the environment, opening it up for extractives practices, by targeting specific peoples.

The Bolsonaro administration employs a violent rhetoric which affirms its hegemony by denying the heterogeneous nature of environmental actors in Brazil, further centralising their control over environmental governance by restricting who is able to engage with national environmental policy. Attacks on environmental defenders seek to criminalise dissent itself (Rocha and Barbosa Jr 2018). ${ }^{27}$ The Bolsonaro administration attacks dissenting voices in efforts to remove their standing as legitimate interlocutors. Such attacks seek to disrupt all possibility of environmental protection by delegitimising environmental defenders seeking to cease processes of everyday dispute for authority between state bodies and the collective demands of groups that challenge them. Such attempts are especially problematic because environmental governance in Brazil was constructed in conjunction with and through the struggles of civil society, NGOs, indigenous and traditional peoples, and other environmental defenders.

\section{Authoritarian environmental populism in Brazil}

To promote 'total extractivism' (Dunlap and Jakobsen 2020), the Bolsonaro administration operates Brazil's environmental governance through a predatory logic that goes beyond primitive accumulation (Sassen 2010, 2015), no longer simply guided by notions of 'progress' or 'growth.' The exclusive interests of a small circle that surrounds state and financial power is promoted. Bolsonaro represents more than the discontinuity of previous policies, his administration ruptures the very idea of environmental protection.

In using the framework provided by Scoones et al. (2018), we offer evidence as to how Bolsonaro centralises environmental governance through both authoritarian (i.e., by restricting access to participatory decision-making processes) and populist (i.e., by attacking environmental defenders) means. To fully understand the processes through which Brazilian environmental protection arrangements are being reshaped, one must analyse the subjective dimensions of efforts that seek to legitimise Bolsonaro's environmental agenda. The two-pronged approach we propose allows analysts to better assess the ways and extent to which the once rich tapestry of plural environmental claims that characterised Brazil (see Hendlin 2019) has been reduced under the Bolsonaro regime.

Bolsonaro's attacks on environmental defenders can be understood as an active effort to direct Brazilian environmental policy towards restricted extractivist inter-

\footnotetext{
26 See www.ecowatch.com/brazil-bolsonaro-bill-open-indigenous-land-2645088985.html and http:// www.brasil.elpais.com/brasil/2020-03-02/a-mineracao-em-terra-indigena-com-nome-sobrenome-e-cnpj. html. Accessed: 01.06.20.

27 As further evidence to this, a recent public hearing in the Chamber of Deputies discussed the criminalisation of indigenous leaders. See http://edemocracia.camara.leg.br/audiencias/sala/1932. Accessed: 01.06.21.
} 
ests. In this way, our main point is that Bolsonaro's attacks are not only rhetorical or disinterested but endowed with practical political implications (i.e., it is a means through which to govern the environment). Such attacks are an active populist effort to centralise the country's environmental governance by effectively restricting who has the legitimacy to make claims on behalf of the environment. This occurs concurrently and in consort with the restrictions on participatory environmental governance spaces, reducing the scope of agencies and actors participating in Brazil's environmental policy. Environmental civil servants are then forced to stand as a resistance of the Bolsonaro administration to protect environmental policy (ASCEMA National 2020). As a result, not only environmental protection legislation and institutions, but the environmental defenders themselves, are framed as obstacles to economic development, recognised as an unquestionable imperative. This is done, in part, by positioning environmental questions as a zero-sum game. Environmental devastation is thus framed as not only acceptable but necessary for economic development.

If before PT-era environmental governance had been marked by a contradictory ambivalence and dispute (i.e., neoextractivism), we conclude that current environmental governance is now centralised to serve a single restrictive set of interests (i.e., total extractivism). Said differently, this marks the transition from neodevelopmentism to a developmental agenda that directly positions environmental governance at the service of extractivist interests. The level through which Brazilian social and environmental policies have been dismantled is without precedence; the Bolsonaro administration does not fit within the binomial 'change or continuity', it lies beyond discontinuity.

\section{Conclusion}

We have argued that Bolsonaro's attacks against specific groups, such as indigenous and traditional peoples, NGOs, scientist, and other environmental defenders, is an effort to reduce their legitimacy, agency, and voices. We conceptualise such environmental populist efforts as key to centralising environmental governance into Brazil's federal government through authoritarian measures that include restricting participatory decision-making spaces. As such, drawing on Scoones et al. (2018), we sought to exemplify the value of analysing 'authoritarianism' and 'populism' together (our approach differs from Daly 2020, who argued for authoritarianism over populism in identifying potential democratic threats in Brazil). The contemporary rise of the farright across the globe has reaffirmed historical examples of how authoritarianism and populism go hand-in-hand. We maintain that Bolsonaro's authoritarian efforts to centralise Brazil's environmental governance have only been possible insofar as they are legitimised by his environmental populism.

Centralisation, as such, relates to the vertical concentration of authority and decision-making power in the federal government itself. Brazilian environmental governance is being purposefully designed to take place almost exclusively through Bolsonaro's administration itself-centralisation in the federal executive branch, as opposed to the state in its entirety. The Bolsonaro administration does this precisely to guarantee better conditions for private actors who support the government. As 
relates to the environment, we reason that centralisation seeks to maintain a programmed inefficiency-e.g., in inhibiting effective oversight and regulatory powers. As Santos (2002, p. 38 our translation) clarifies, phenomena such as 'total extractivism' "can only be achieved through strong state intervention. The state must intervene to stop intervening, that is, it has to regulate its own deregulation."

Our paper seeks to advance current understanding of the conditions that have allowed contemporary Brazilian environmental politics to be at odds with the global environmental agenda, and points towards the dangers of this in connection to environmental populism elsewhere. Moving forward, we must fight to overcome rightwing populism and build alternatives towards emancipatory horizons (Borras Jr. 2020). Since the struggle to defend the environment in Brazil is linked to territorial rights of indigenous and traditional peoples, to enact environmental protection under Bolsonaro's regime we must seek to strengthen indigenous and traditional peoples' rights (see also Levis et al. 2020). To achieve this, we must ensure that environmental protection is not only placed at the forefront of social demands but that such conversations are led by a plurality of subjects through effective participatory means with actual decision-making power. We must consider attacks against environmental defenders as an attack on the environment itself.

Acknowledgements We thank the special issue guest editors and especially ZfVP's Managing Editor, Christoph Mohamad-Klotzbach, as well as the two anonymous reviewers whose attentive reading of and critical engagement with our work has allowed us to clarify and add nuance to our argument. We also thank Danilo Borja, Pedro Vasconcelos, Matheus Pfrimer, Gabriel Soyer, Estevan Coca, Rodrigo Führ, Rafael Mello, and Shelby Montgomery for their helpful comments on previous versions of the manuscript. Any shortcomings or mistakes are our own, of course. Menezes thanks the Federal District Research Founda-

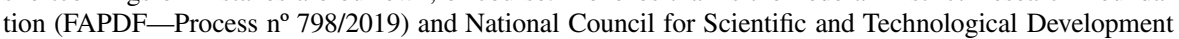
(CNPq) Fellow Researcher programme for supporting this research.

Conflict of interest R. G. Menezes and R. Barbosa Jr declare that they have no competing interests.

\section{References}

Abessa, Denis, Ana Famá, and Lucas Buruaem. 2019. The systematic dismantling of Brazilian environmental laws risks losses on all fronts. Nature Ecology \& Evolution 3:510-511. https://doi.org/10. 1038/s41559-019-0855-9.

Acosta, Alberto. 2013. Extractivism and neoextractivism: two sides of the same curse. In Beyond development: alternative visions from latin America, ed. Imre Szúcs, 61-86. Quito, Amsterdam: Transnational Institute / Rosa Luxemburg Foundation.

Andrade, Daniela. 2016. 'Export or die': the rise of Brazil as an agribusiness powerhouse. Third World Thematics: A TWQ Journal 1:653-672. https://doi.org/10.1080/23802014.2016.1353889.

Andrade, Daniela. 2019. Populism from above and below: the path to regression in Brazil. The Journal of Peasant Studies https://doi.org/10.1080/03066150.2019.1680542.

de Araújo, Suely Mara Vaz Guimarães. 2020. Environmental policy in the Bolsonaro government: the response of environmentalists in the legislative arena. Brazilian Political Science Review 14:e5. https:// doi.org/10.1590/1981-3821202000020005.

Aronoff, Kate. 2019. The European Far Right's environmental turn. Dissent, May 31. www.dissentmagazine. org/online_articles/the-european-far-rights-environmental-turn. Accessed 01.06.20.

Arsel, Murat, Barbara Hogenboom, and Lorenzo Pellegrini. 2016. The extractive imperative and the boom in environmental conflicts at the end of the progressive cycle in Latin America. The Extractive Industries and Society 3:877-879. https://doi.org/10.1016/j.exis.2016.10.013.

ASCEMA National. 2020. Chronology of an announced disaster: actions of the Bolsonaro government to dismantle environmental policies in Brazil. : Associação Nacional dos Servidores de Meio Ambiente. 
Barbosa, Ricardo, Jr., and João Roriz. 2021. The subversive practice of counting bodies: documenting violence and conflict in rural Brazil. Journal of Agrarian Change https://doi.org/10.1111/joac.12416.

Barbosa Gomes, Luciana, Maria Alice Alves Santos, and Carlos Eduardo Viveiros Grelle. 2021. Actions against sustainability: dismantling of the environmental policies in Brazil. Land Use Policy 104:105384. https://doi.org/10.1016/j.landusepol.2021.105384.

Bolsonaro, Jair. 2018. Plano de Governo: Brasil acima de tudo; Deus acima de todos. Brasília: TSE.

Borras Jr., Saturnino M.. 2020. Agrarian social movements: the absurdly difficult but not impossible agenda of defeating right-wing populism and exploring a socialist future. Journal of Agrarian Change 20:3-36. https://doi.org/10.1111/joac.12311.

Braga, Ruy, and Sean Purdy. 2019. A precarious hegemony: neo-liberalism, social struggles, and the end of Lulismo in Brazil. Globalizations 16:201-215. https://doi.org/10.1080/14747731.2018.1479013.

Broz, J. Lawrence, Jeffry Frieden, and Stephen Weymouth. 2021. Populism in place: the economic geography of the globalization backlash. International Organization https://doi.org/10.1017/S0020818320 000314.

Bruff, Ian, and Cemal Burak Tansel. 2019. Authoritarian neoliberalism: trajectories of knowledge production and praxis. Globalizations 16:233-244. https://doi.org/10.1080/14747731.2018.1502497.

Carneiro, Ricardo. 2002. Desenvolvimento em crise. São Paulo: Unesp/Unicamp.

Casarões, Guilherme, and Daniel Flemes. 2019. Brazil First, Climate Last: Bolsonaro's Foreign Policy, GIGA Focus Latin America, September 5, www.gigahamburg.de/en/publication/brazil-first-climatelast-bolsonaros-foreign-policy. Accessed 01.06.20.

de Castro, Fábio. 2014. Environmental policies in the Lula era: accomplishments and contradictions. In Brazil under the workers' party, ed. Fábio de Castro, Kees Koonings, and Marianne Wiesebron, 229-255. London: Palgrave Macmillan.

Chase, Veronika Miranda. 2019. The changing face of environmental governance in the Brazilian Amazon: indigenous and traditional peoples promoting norm diffusion. Revista Brasileira de Política Internacional 62:1-20.

Coca, Estevan. 2021. Food procurement in post-neoliberal countries: examples from South America. Agrarian South: Journal of Political Economy 10:1-21. https://doi.org/10.1177/22779760211032067.

Daly, Tom Gerald. 2020. Understanding multi-directional democratic decay: lessons from the rise of Bolsonaro in Brazil. The Law \& Ethics of Human Rights 14:199-226. https://doi.org/10.1515/lehr-20202014.

Diniz, Eli. 2013. Desenvolvimento e Estado desenvolvimentista: tensões e desafios da construção de um novo modelo para o Brasil do século XXI. Revista de Sociologia e Política 21:9-20. https://doi.org/ 10.1590/S0104-44782013000300002.

Dunlap, Alexander, and Jostein Jakobsen. 2020. The violent technologies of extraction: political ecology, critical agrarian studies and the capitalist worldeater. Cham: Palgrave Macmillan.

Eichengreen, Barry. 2018. The populist temptation: economic grievance and political reaction in the modern era. Oxford: Oxford University Press.

Escobar, Herton. 2018. Scientists, environmentalists brace for Brazil's right turn. Science 362:273. https:// doi.org/10.1126/science.362.6412.273.

de Faria Salles, Camila, Diogo de Oliveira, and Teresa Paris Buarque de Hollanda. 2018. Reconhecimento dos direitos territoriais indígenas no governo Temer: omissão e retrocessos. Revista OKARA: Geografia em Debate 12:477-506. https://doi.org/10.22478/ufpb.1982-3878.2018v12n2.41327.

Fearnside, Phillip M. 2006. Dams in the Amazon: belo monte and Brazil's hydroelectric development of the Xingu river basin. Environmental Management 38:16. https://doi.org/10.1007/s00267-005-01136.

Fiori, José Luis. 2007. O Poder global e a nova geopolítica das nações. São Paulo: Boitempo.

Fischer, Andrew M. 2020. The dark sides of social policy: from neoliberalism to resurgent right-wing populism. Development and Change 51:371-397. https://doi.org/10.1111/dech.12577.

Forchtner, Bernhard. 2019. Climate change and the far right. WIREs Climate Change 10:e604. https://doi. org/10.1002/wcc.604.

Forchtner, Bernhard (ed.). 2020. The far right and the environment: politics, discourse and communication. London, New York: Routledge.

Gonçalves, Reinaldo. 2013. Desenvolvimento às avessas. Rio de Janeiro: LTC.

Guajajara, Sônia. 2020. Governo Bolsonaro: o retrato da barbárie contra os povos indígenas e a vida. In Conflitos no campo: Brasil 2019, 182-189. Goiânia: CPT Nacional.

Gudynas, Eduardo. 2015. Extractivismos en América del Sur y sus efectos derrame. Bulletin De La Société Suisse des Américanistes 76:13-23. 
Gudynas, Eduardo. 2020. Ecología política del fuego: ambiente y desarrollo en los incendios sudamericanos de 2019. In Informe Ambiental 2020: Lo ambiental debe ser política de Estado, Vol. 12, ed. Andrés Nápoli, Pía Marchegiani, 40-50. Buenos Aires: Fundación Ambiente y Recursos Naturales.

Hendlin Hale, Yogi. 2019. Environmental justice as a (potentially) hegemonic concept: a historical look at competing interests between the MST and indigenous people in Brazil. Local Environment 24:113-128. https://doi.org/10.1080/13549839.2018.1488823.

Heydarian, Richard. 2018. The rise of Duterte: a populist revolt against elite democracy. London: Palgrave Macmillan.

Hopwood, Bill, Mary Mellor, and Geoff O’Brien. 2005. Sustainable development: mapping different approaches. Sustainable Development 13:38-52. https://doi.org/10.1002/sd.244.

Hunter, Wendy. 2010. The Transformation of the Workers' Party in Brazil, 1989-2009. Cambridge: Cambridge University Press.

INPE. 2020. Dados Abertos. : Instituto Nacional de Pesquisas Espaciais.

Kiely, Ray. 2020. Assessing conservative populism: a new double movement or neoliberal populism? Development and Change 51:398-417. https://doi.org/10.1111/dech.12567.

Kröger, Markus. 2020a. Field research notes on Amazon deforestation during the Bolsonaro era. Globalizations 17:1080-1083. https://doi.org/10.1080/14747731.2020.1763063.

Kröger, Markus. 2020b. Deforestation, cattle capitalism and neodevelopmentalism in the Chico Mendes Extractive Reserve, Brazil. The Journal of Peasant Studies 47:464-482. https://doi.org/10.1080/ 03066150.2019.1604510.

Leite Boaventura, Ilka. 2015. The Brazilian quilombo: 'race', community and land in space and time. The Journal of Peasant Studies 42:1225-1240. https://doi.org/10.1080/03066150.2015.1016919.

Levis, Carolina, Bernardo M. Flores, Guilherme G. Mazzochini, Adriana P. Manhães, João Vitor CamposSilva, Pablo Borges de Amorim, Nivaldo Peroni, Marina Hirota, and Charles R. Clement. 2020. Help restore Brazil's governance of globally important ecosystem services. Nature Ecology \& Evolution 4:172-173. https://doi.org/10.1038/s41559-019-1093-x.

Li Murray, Tania. 2019. Politics, interrupted. Anthropological Theory 19:29-53. https://doi.org/10.1177/ 1463499618785330.

Lockwood, Matthew. 2018. Right-wing populism and the climate change agenda: exploring the linkages. Environmental Politics 27:712-732. https://doi.org/10.1080/09644016.2018.1458411.

McCarthy, James. 2019. Authoritarianism, populism, and the environment: comparative experiences, insights, and perspectives. Annals of the American Association of Geographers 109:301-313. https:// doi.org/10.1080/24694452.2018.1554393.

Milanez, Felipe. 2020. Cuerpo y alma del fascismo contemporáneo en Brasil: la ecología política del racismo y del extractivismo. Ecología Política 59:17-23.

de Moura, Adriana Maria Magalhães. 2016. Trajetória da política ambiental federal no Brasil. In Governança ambiental no Brasil: instituições, atores e políticas públicas, ed. Adriana Maria Magalhães de Moura, 13-44. Brasília: IPEA.

Neimark, Benjamin, John Childs, Andrea J. Nightingale, Connor Joseph Cavanagh, Sian Sullivan, Tor A. Benjaminsen, Simon Batterbury, Stasja Koot, and Wendy Harcourt. 2019. Speaking power to "post-truth": critical political ecology and the new authoritarianism. Annals of the American Association of Geographers 109:613-623. https://doi.org/10.1080/24694452.2018.1547567.

Niederle, Paulo, Catia Grisa, Everton Picolotto Lazaretti, and Denis Soldera. 2019. Narrative disputes over family-farming public policies in Brazil: conservative attacks and restricted countermovements. Latin American Research Review 54:707-720. https://doi.org/10.25222/larr.366.

North, Liisa L., and Ricardo Grinspun. 2016. Neo-extractivism and the new Latin American developmentalism: the missing piece of rural transformation. Third World Quarterly 37:1483-1504. https://doi. org/10.1080/01436597.2016.1159508.

Nunes, João, and Alejandro Milciades Peña. 2015. Marina Silva and the rise of sustainability in Brazil. Environmental Politics 24:506-511. https://doi.org/10.1080/09644016.2015.1008682.

Ostrom, Elinor. 2010. Polycentric systems for coping with collective action and global environmental change. Global Environmental Change 20:550-557. https://doi.org/10.1016/j.gloenvcha.2010.07. 004.

Pahnke, Anthony. 2018. The contradictions of neo-extractivism and social policy: the role of raw material exports in the Brazilian political crisis. Third World Quarterly 39:1656-1674. https://doi.org/10.1080/ 01436597.2018.1428088.

Pereira Mendes, João Márcio. 2015. Continuidade, Ruptura ou Reciclagem? Uma Análise do Programa Político do Banco Mundial após o Consenso de Washington. Dados 58:461-498. 
Pfrimer Hoffmann, Matheus, and Ricardo Barbosa Jr.. 2020. Brazil's war on COVID-19: Crisis, not conflict-Doctors, not generals. Dialogues in Human Geography 10:137-140. https://doi.org/10.1177/ 2043820620924880.

Pinheiro, Victor Marcel, Marcelo Ilarraz, and Melissa Terni Mestriner. 2020. The impacts of the COVID19 crisis on the Brazilian legal system - a report on the functioning of the branches of the government and on the legal scrutiny of their activities. The Theory and Practice of Legislation 8:193-212. https:// doi.org/10.1080/20508840.2020.1790104.

Policia Federal. 2020. Laudo de Perícia Criminal Federal: $N^{o}$ 1242/2020. Brasília: INC/DITEC/PF.

Reis da Silva, Ana Tereza. 2015. A conservação da biodiversidade entre os saberes da tradição e a ciência. Estudos Avançados 29:233-259. https://doi.org/10.1590/S0103-40142015000100012.

Rocha Vasconcelos, Pedro, and Ricardo Barbosa Jr.. 2018. Criminalizar é governar: uma proposta teórica para a compreensão da criminalização dos movimentos sociais do campo no Brasil. Colombia Internacional https://doi.org/10.7440/colombiaint93.2018.08.

Rydgren, Jens (ed.). 2018. The Oxford handbook of the radical right. New York: Oxford University Press. Sader, Emir. 2009. Postneoliberalism in Latin America. Development Dialogue 51:171-180.

de Sá Dominichi, Miranda, Magali Romero Sá, and Nísia Trindade Lima. 2008. Telégrafos e inventário do território no Brasil: as atividades científicas da Comissão Rondon (1907-1915). História, Ciências, Saúde-Manguinhos 15:779-810. https://doi.org/10.1590/S0104-59702008000300011.

Samuels, David. 2004. From socialism to social democracy: party organization and the transformation of the workers' party in Brazil. Comparative Political Studies 37:999-1024. https://doi.org/10.1177/ 0010414004268856.

Santos, Boaventura Souza. 2002. Os processos de globalização. In Globalização e Ciências Sociais, ed. Boaventura Souza Santos, 25-102. São Paulo: Cortez.

Sassen, Saskia. 2010. A savage sorting of winners and losers: contemporary versions of primitive accumulation. Globalizations 7:23-50. https://doi.org/10.1080/14747731003593091.

Sassen, Saskia. 2015. Conclusion: emergent predatory logics. In Handbook of the international political economy of production, ed. Kees van der Pijl, 524-541. Cheltenham: Edward Elgar Publishing.

Sauer, Sérgio. 2017. Rural Brazil during the Lula administrations: agreements with agribusiness and disputes in agrarian policies. Latin American Perspectives 46:103-121. https://doi.org/10.1177/ $0094582 X 16685176$.

Sauer, Sérgio, Moisés V. Balestro, and Sergio Schneider. 2018. The ambiguous stance of Brazil as a regional power: piloting a course between commodity-based surpluses and national development. Globalizations 15:32-55. https://doi.org/10.1080/14747731.2017.1400232.

Schincariol, Vitor Eduardo, and Paris Yeros. 2019. The political economy of 'impeachment' in Brazil: an assessment of the Temer interlude (2016-2018). Revista Galega de Economía 28:73-90. https://doi. org/10.15304/rge.28.1.6165.

Scoones, Ian, Marc Edelman, Saturnino M. Borras Jr., Ruth Hall, Wendy Wolford, and Ben White. 2018. Emancipatory rural politics: confronting authoritarian populism. The Journal of Peasant Studies 45:1-20. https://doi.org/10.1080/03066150.2017.1339693.

Singer, André. 2012. Os sentidos do lulismo: reforma gradual e pacto conservador. São Paulo: Companhia das Letras.

Singer, André. 2018. O lulismo em crise: um quebra-cabeça do período Dilma (2011-2016). São Paulo: Companhia das Letras.

Siqueira-Gay, Juliana, Aurora Miho Yanai, Janeth Lessmann, Ana Carolina M. Pessôa, Danilo Borja, Moara Canova, and Rafael Cabral Borges. 2020. Pathways to positive scenarios for the Amazon forest in Pará state, Brazil. Biota Neotropica 20:1-18. https://doi.org/10.1590/1676-0611-bn-20190905.

de Souza, Marcelo Lopes. 2020. The land of the past? Neo-populism, neo-fascism, and the failure of the left in Brazil. Political Geography 83:102186. https://doi.org/10.1016/j.polgeo.2020.102186.

Soyer, Gabriel, and Ricardo Barbosa Jr.. 2020. O extrativismo agrário do Governo Bolsonaro a partir das relações Estado-Sociedade. Revista da ANPEGE 16:516-548. https://doi.org/10.5418/ra2020.v16i29. 12553.

Stabile, Marcelo C.C., André L. Guimarães, Daniel S. Silva, Vivian Ribeiro, Marcia N. Macedo, Michael T. Coe, Erika Pinto, Paulo Moutinho, and Ane Alencar. 2020. Solving Brazil's land use puzzle: Increasing production and slowing Amazon deforestation. Land Use Policy 91:104362. https://doi.org/ 10.1016/j.landusepol.2019.104362.

Stoner, Alexander M. 2020. Critical reflections on America's green new deal: capital, labor, and the dynamics of contemporary social change. Capitalism Nature Socialism https://doi.org/10.1080/10455752. 2020.1775860 . 
Svampa, Maristella. 2019. Neo-extractivism in latin America: socio-environmental conflicts, the territorial turn, and new political narratives. Lements in politics and society in latin america. Cambridge: Cambridge University Press.

Tavares, Francisco, and Gustavo Silva. 2020. A Ciência Política Brasileira Diante do Novo Regime Fiscal: Para uma Agenda de Pesquisas sobre Democracia e Austeridade. Dados 63:1-39. https://doi.org/10. 1590/001152582020207.

Teixeira, Raquel Oliveira Santos, Andréa Luisa Zhouri, and Luana Dias Motta. 2021. Os estudos de impacto ambiental e a economia de visibilidades do desenvolvimento. Revista Brasileira de Ciências Sociais 36:1-18. https://doi.org/10.1590/3610501/2020.

Tilzey, Mark. 2019. Authoritarian populism and neo-extractivism in Bolivia and Ecuador: the unresolved agrarian question and the prospects for food sovereignty as counter-hegemony. The Journal of Peasant Studies 46:626-652. https://doi.org/10.1080/03066150.2019.1584191.

Vanaik, Achin. 2017. The rise of hindu authoritarianism: secular claims, communal realities. London: Verso.

Ventura, Zuenir. 2003. Chico Mendes: crime e castigo. São Paulo: Companhia das Letras.

Vergara-Camus, Leandro, and Cristóbal Kay. 2017. The agrarian political economy of left-wing governments in Latin America: Agribusiness, peasants, and the limits of neo-developmentalism. Journal of Agrarian Change 17:415-437. https://doi.org/10.1111/joac.12216.

Walker, R.B.J., Robbie Shilliam, Heloise Weber, and Gitte Du Plessis. 2018. Collective discussion: diagnosing the present. International Political Sociology 12:88-107. https://doi.org/10.1093/ips/olx022.

Wittman, Hannah, and Jennifer Blesh. 2017. Food sovereignty and fome zero: connecting public food procurement programmes to sustainable rural development in Brazil. Journal of Agrarian Change 17:81-105. https://doi.org/10.1111/joac.12131.

Zhouri, Andréa. 2014. Mapeando desigualdades ambientais. Mineração e desregulação ambiental. In Formas de matar, de morrer e de resistir, ed. Andréa Zhouri, Norma Valencio, 111-141. Belo Horizonte: UFMG.

Żuk, Piotr, and Kacper Szulecki. 2020. Unpacking the right-populist threat to climate action: Poland's pro-governmental media on energy transition and climate change. Energy Research \& Social Science 66:101485. https://doi.org/10.1016/j.erss.2020.101485. 